\title{
Protection of renal function by four selected plant extracts during Plasmodium berghei infection
}

\author{
Adewale Adetutu, Olubukola Sinbad Olorunnisola, and Kazeem Iyanda
}

Department of Biochemistry, Ladoke Akintola University of Technology, Ogbomoso, Nigeria

Correspondence Author: Adewale Adetutu, $\mathrm{PhD}$, Department of Biochemistry, Ladoke Akintola University of Technology, Ogbomoso, Nigeria

Submission Date: July 5, 2015, Acceptance date: October 27, 2015: Publication date: October 29,2015

\begin{abstract}
The weakening of renal function from reactive oxygen species, which is generated during malaria infection, is one of the prominent causes of death in prevalent regions throughout the world. The potential toxicity of free radical generated by malaria parasites are counteracted by a large number of cytoprotective phytochemicals. Therefore, this study examined the influence of extracts of five selected antimalarial plants (Azadirachta indica, Parquetina nigrescens, Citrus paradisi, and Khaya senigalensis) on the reduction of inflammation in renal tissue, blood urea nitrogen, and creatinine levels during malaria infection using Plasmodium berghei infected Swiss albino mice. For in vivo assay, mice were inoculated with $1 \times 10^{7}$ parasitized erythrocytes and plant extracts were subsequently administered orally at $100 \mathrm{mg} / \mathrm{kg}$ body weight once a day for 17 consecutive days. The chemo-suppressive and prophylaxis effects of the plant extracts against $P$. berghei were investigated and compared with those of standard antimalarial drug, chloroquine. Tail bleeding was performed to check the percentage parasitaemia by making a thin film smear on a slide, stained in Giemsa. The numbers of parasited cells against the unparasitised cells were counted using a microscope. The effect of malaria infection on renal tissue was assessed by histological analysis and measurement of blood urea nitrogen and creatinine levels in plasma. At $100 \mathrm{mg} / \mathrm{kg}$ per body weight, aqueous extract of $K$. senegalensis, A. indica, $C$. paradisi and $P$. nigrescens exhibited significant $(p<0.05)$ percentage inhibition and chemo-suppressive effects in comparison with the chloroquine treated mice. The results of the untreated group showed that there was a significant $(\mathrm{p}<0.05)$ increase in the level of plasma urea, while the level of the groups treated with plants extract stabilized the level of urea and creatinine in the blood. Additionally, there was a pathological lesion on the kidney tissue of the untreated group, whereas the group treated with aqueous extract of $A$. indica, Khaya senegalensis and $C$. paradisi showed no lesion. Therefore, it can be assumed that the extracts can protect and preserve renal function during malaria infection. These findings justified the use of the extracts in traditional medicine practice, for the treatment of malaria infection.
\end{abstract}

Key words: Plasmodium berghei, antimalarial plants, renal function, antiplasmodium 


\section{INTRODUCTION}

Malaria is one of the world's signficiant public health challenges, compromising development in poverty-stricken countries and accounting up to an overwhelming 2.7 million death per annum [1]. Malaria is caused by an infection from the intracellular apicomplexan parasites of the Plasmodium genus. The most common and severe genus affecting humans is $P$. falciparum [2]. $P$. falciparum can invade a large percentage of the red blood cells and cause severe anaemia and multiple complications of cerebral malaria, respiratory distress, hepatic and renal dysfunctions. Malaria related renal damage may be connected with oxidative stress during malaria infection $[3,4]$. Renal cell histological assessment and measurement of activities of blood urea nitrogen and creatinine level can be used as key indications to study renal dysfunction during malaria [3]. Elevated level of creatinine and urea can be seen in any kind of renal disorder like glomerular nephritis, chronic nephritis and nephritic syndrome [4]. These key markers have encouraged investigation towards the detection and development of compounds to protect or reduce renal damage during malaria infection [5,6].

The reported use of some plants in the treatment of malaria by local healers in Nigeria has generated interest in searching for possible antimalarial efficacy in plants. Consequently, medicinal plants are potential targets for alternative antimalarial agents, as a supplement or used in combination with standard antimalarial drugs [7,8,9]. K. senegalensis, A. indica, C. paradisi and $P$. nigrescens were selected for this study because of their popular usage for malarial treatment in Nigeria. The stem-back and leaves of $K$. senegalensis have been used in Northern Nigeria in forms of decoction and concoctions for the cure of mucous diarrhea, syphilis and malarial fever [10,11]. A. indica is traditionally used for the treatment of malaria, urinary diseases, piles, leprosy, intestinal worms and psoriasis [12]. P. nigrescens leaf decoction is taken to treat serious kidney problems and severe constipation. Fresh crushed leaves are taken to treat severe constipation [13]. C. paradisi decoctions of the leaves, flowers, fruits and seeds have properties, which can treat coughs, malaria and gastric disorders [13]

Therefore, this study examined the renal protective effects of the aqueous extract of four selected plants on $P$. berghei infected mice. The study analyzed the level of plasma creatinine and urea level and chemo-suppressive effect of the aqueous extract of the plants in $P$. berghei infected mice. This study also focused on histological analysis of the renal tissue to monitor the efficacy of the selected plant extracts on reduction of renal injury during malaria infection using the $P$. berghei infected mouse model.

\subsection{MATERIALS AND METHODS}

\subsection{Plant materials and antimalarial drug}

Fresh leaves of $K$. senegalensis, $P$. nigrescens, $C$. paradisi and A. indica were collected from Ladoke Akintola University of Technology (LAUTECH) Research Farm, Nigeria in February, 2014. The plants were identified and authenticated by Dr A.J Ogunkunle and the voucher specimens were deposited in the herbarium of the Department of Pure and Applied Biology, LAUTECH, Nigeria. The voucher numbers were assigned as UIH852 (K. senegalensis), UIH800 (C. paradisi), UIH979 (A. indica) and UIH876 ( $P$. nigrescens). The leaves were air dried for two weeks at room temperature and ground into powder. One hundred grams of each of the powdered plant materials were soaked in $1000 \mathrm{~mL}$ distilled water at $4^{\circ} \mathrm{C}$ for $72 \mathrm{hr}$ and filtrated. The filtrate 
was then freeze dried. Standard antimalarial drug, chloroquine, was used as a positive control to study in vivo drug susceptibility of $P$. berghei. Chloroquine and plant extracts was prepared in distilled water and administered orally at 5 and $100 \mathrm{mg} / \mathrm{kg}$ per body weight respectively.

\subsection{Experimental animals}

Pathogen free Swiss albino mice weighing 20-24g obtained from Animal House LAUTECH, Ogbomoso were used in this study. The mice were divided into four groups housed in different cages and acclimatized for a week. Permission and approval for animal experiments were ratified by the Animal Ethics Committee, Faculty of Basic Medical Sciences, and LAUTECH. The mice were treated as detailed in Table 1.

Table 1: Protocol for Treatment of Mice

\begin{tabular}{|l|l|}
\hline Group & Treatment \\
\hline Positive control & Administered with distilled water alone \\
\hline Negative control & Inoculated with $P$. berghie without treatment \\
\hline Standard (Chloroquine) Control & $\begin{array}{l}\text { Inoculated with } P . \text { berghie and treated with } 5 \mathrm{mg} / \mathrm{kg} \text { body weight of } \\
\text { chloroquine }\end{array}$ \\
\hline Plant extract & $\begin{array}{l}\text { Inoculated with } P . \text { berghie and treated with aqueous extract of } 100 \mathrm{mg} / \mathrm{kg} \\
\text { body weight of } P . \text { negresens } \text { or } K . \text { senegalensis, or } C \text {. paradise or } A . \text { indica }\end{array}$ \\
\hline
\end{tabular}

\subsection{Parasite and infection of mice}

$P$. berghei, a chloroquine-sensitive strain, was used in this study. Parasitized erythrocytes were obtained from a donor infected mice of which the parasite was maintained by continuous reinfestation in mice. This inoculum was prepared by determining the percentage parasitemia and the erythrocytes count of the donor mouse and assessed daily by conventional microscopic examination of Giemsa stained thin blood smear. Each mouse was inoculated intraperitoneally with $0.2 \mathrm{~mL}$ of infected blood suspension containing $1 \times 10^{7}$ P. berghei parasitized red blood cell, Representative of the slides with parasitized and unparasitised red blod cell is shown in Fig. 1.

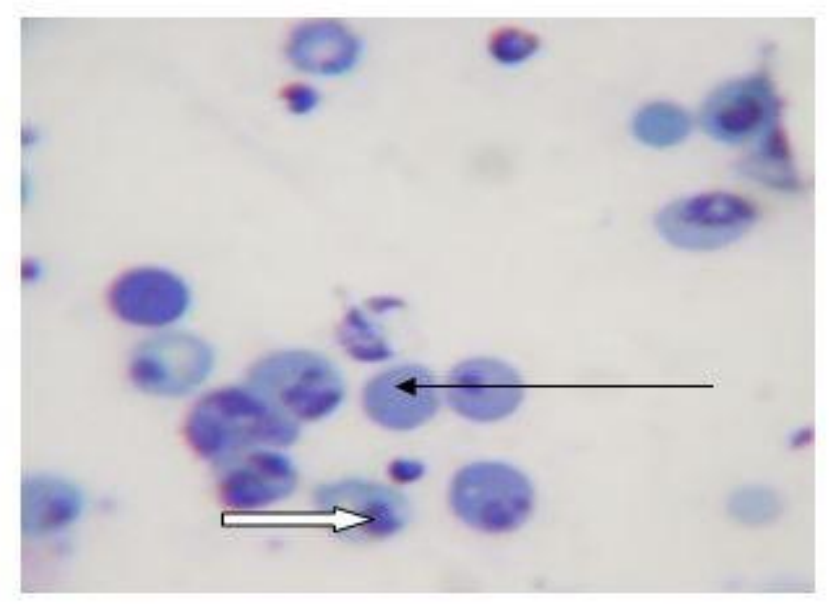

Fig. 1. Photomi crograph of para sitized RBC, normal RBC. Parasitized erythrocyte cell (white arrow) stained with $10 \%$ Giemsa stain, normal RBC (slender arrow) with magnification power $400 \times$. 


\subsection{Evaluation of renal function}

Blood was collected from the tail of the mice in the heparinized tube and centrifuged at $10,000 \mathrm{~g}$ for $10 \mathrm{~min}$. Plasma was then collected into another microcentrifuge tube and used for blood urea and creatinine measurements. Levels of urea and creatinine in plasma were measured using a commercial kit (BIORAD), according to the manufacturer's instruction.

\subsection{Antiplasmodial in vivo efficacy test on selected plants}

A modification of Peters et al [14] and Peters et al [15] methods was adopted for suppressive and curative test. The mice were selected into groups of 5 mice per cage (Table 1). Twenty five male Swiss albino mice were inoculated by intraperitoneal injection with standard inoculums of $P$. berghei containing $1 \times 10^{7}$ infected erythrocytes. The mice were administered orally for 4 consecutive days with $100 \mathrm{mg} / \mathrm{kg}$ of aqueous extract, chloroquine of $5 \mathrm{mg} / \mathrm{kg}$ and distilled water. On the fifth, sixth, seventh, eighth and fourteenth days, blood was collected from the tail of each mice and thin film made on slide. The films were fixed with methanol and stained with $10 \%$ Giemsa and the parasitemia density examined by microscopically counting of parasitized red blood cell against normal RBC.

\subsection{Histopathological analysis of the kidney tissue}

The mice were anesthetized in diethylether for a while. The mice were then dissected with dissecting kits to remove the kidney and the liver for pathological studies. The weights of the organs were taken after removal which was fixed in $10 \%$ formalin in a universal bottle. The samples were kept in the refrigerator for 24hours. The tissues were analysed according to the methods of Dacie and Lewis, [16].

\subsection{Statistics}

Statistical analyses of the data were performed using Graph Pad Prism 5 Software (Graph Pad Software, Inc., US). A one way ANOVA test was used to compare the results at a $99 \%$ confidence level. Values of $\mathrm{p}>0.01$ were considered significant. Results were expressed as mean \pm standard error of mean $(\mathrm{SEM})$.

\subsection{RESULTS}

\subsection{Antiplasmodial effect of aqueous extract of the selected plants}

Administration of the extract commenced three hours after infection, a time when parasitemia was established in all the animals. There was a steady increase in the level of the malaria parasite in the untreated group. After three days of the treatment there was a gradual significant decrease ( $>0.05$ ) in the level of the percentage parasitemia (from day 4 - 14) in the group treated at 100 $\mathrm{mg} / \mathrm{kg}$ body weight of the extracts when compared with the groups infected with $P$. berghei. Correspondingly, $5 \mathrm{mg} / \mathrm{kg}$ body weight of chloroquine gradual reduced the level of parasite density (Fig. 2).

The administration of aqueous extracts of $K$. senegalenses and $P$. negresens at $100 \mathrm{mg} / \mathrm{kg}$ body weight significantly decreased $(\mathrm{p}>0.05)$ the number of $P$. berghei (Fig. 2). Similarly, treatment with aqueous extract of $A$. indica after four days of infection significant ( $\mathrm{p}>0.05$ ) suppressed the level of parasite in comparison with group infected with $P$. berghei without 
treatment (Fig. 2). Furthermore, the group treated with $100 \mathrm{mg} / \mathrm{kg}$ body weight of aqueous extract of $C$. paradisi leave exhibited the most significant ( $>>0.01$ ) prophylactic effect by reducing the level of the parasite gradually with a percentage inhibition better than the positive control, chloroquine (Fig. 2).

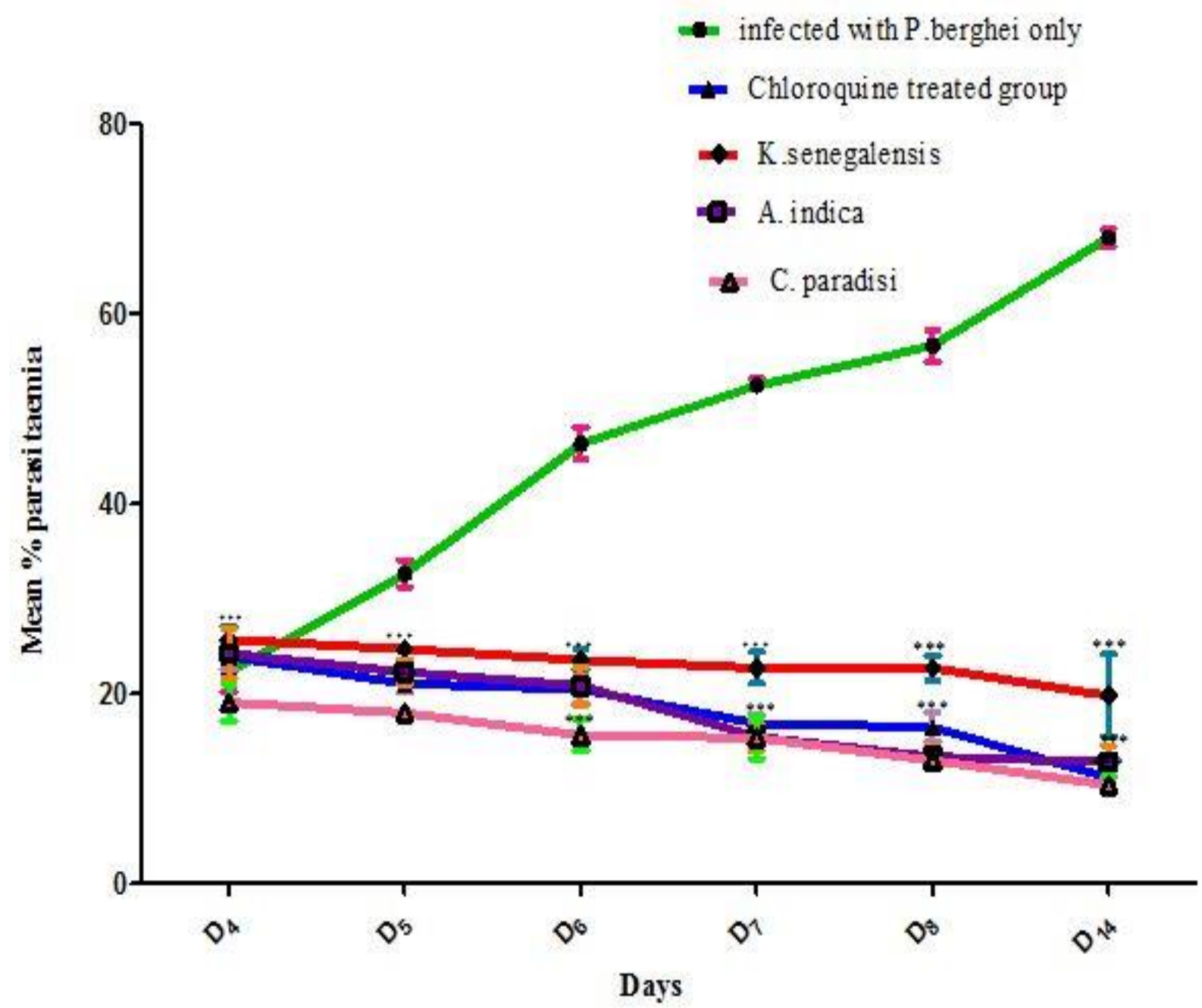

Figure 2. The effect of aqueous extracts of $K$. senegalensis, A. indica, and $C$. paradisi on $P$. berghei infected mice.

$* * *=$ highly significant at $(\mathrm{P}<0.01)$ in comparison with the control. D4-D14 means day 4 to day 14

\subsubsection{Effect of the extract of selected plants on renal function of mice infected with $P$. berghei}

Mice infected with $P$. berghei and treated orally with extract of the selected plants were assessed for possible influence on plasma urea and creatinine levels. There was an increase in the level of the parasite in the untreated groups, resulting in an elevated level of creatinine in the blood. The mice treated with aqueous extract of $A$. indica. $P$. nigrescens, $C$. paradisi and $K$. senegalensis showed variation in the level of creatinine reduction in the plasma (Fig. 3). Likewise, there was high concentration of plasma urea in the untreated group. After oral administration of the plant 
extracts, plasma urea levels declined significantly $(\mathrm{p}<0.05)$ as compared with untreated group (Fig. 4).

Group $1=$ fed with distilled water only. Group $2=$ infected with P. berghei only. Group $3=$ chloroquine treated group. Group $4=100 \mathrm{mg} / \mathrm{kg}$ body weight of aqueous extract of $A$. indica, $P$. negrescens, $C$. paradisi, and $K$. senegalensis. Bar graphs indicate the mean \pm standard error of mean $(\mathrm{SEM})$ of five treatments. $* \mathrm{p}<0.01$ compared with distileed water group. \#p<0.01 compared with $P$. berghei group.

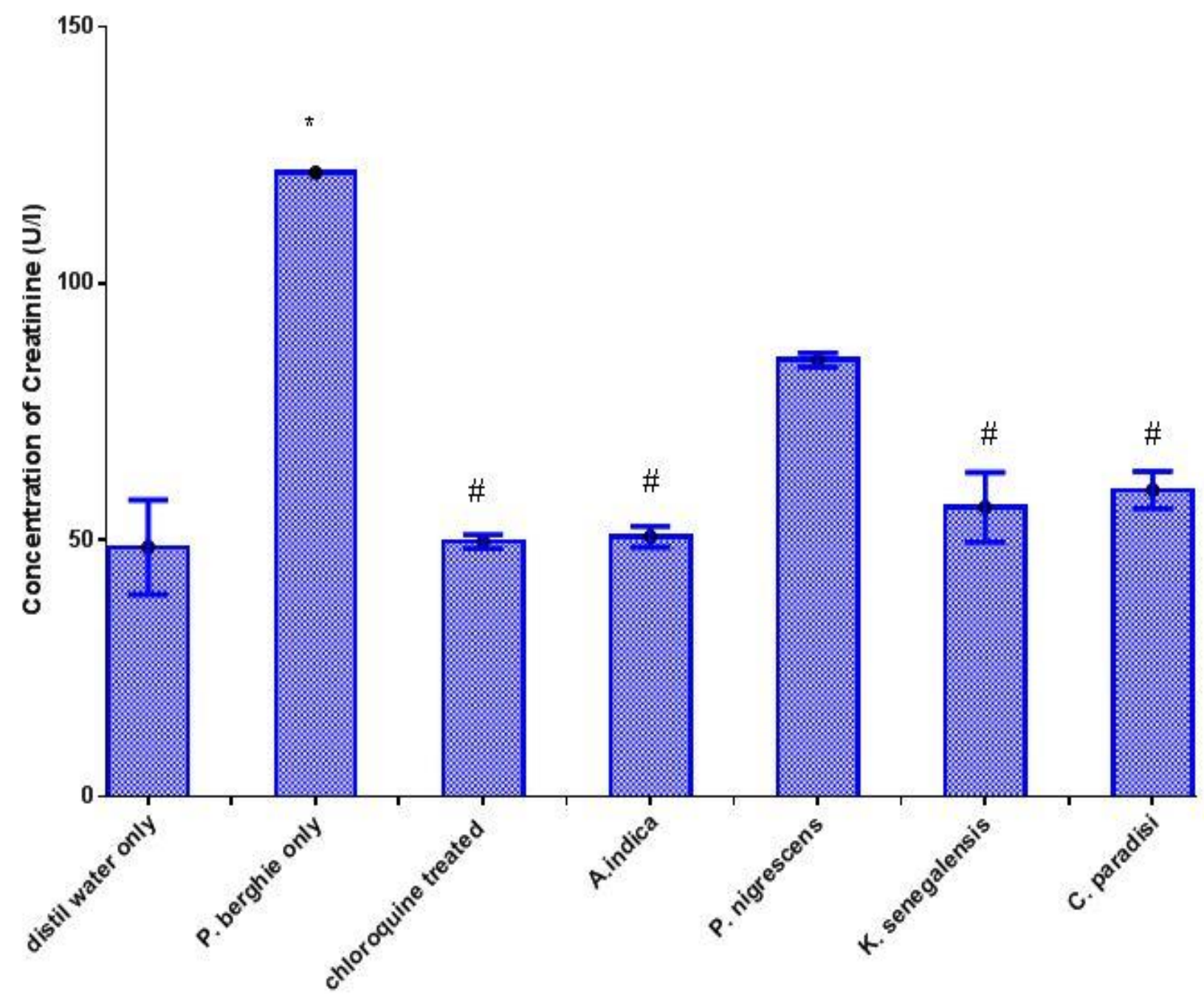

Figure 3: Effect of aqueous extract of $A$. indica, $C$. paradisi, $P$. nigrescens and $K$. senegalensis on Creatinine activity in Mice. Group $1=$ fed with distilled water only. Group $2=$ infected with P. berghei only. Group $3=$ chloroquine treated group. Group $4=100 \mathrm{mg} / \mathrm{kg}$ body weight of aqueous extract of $A$. indica, $P$. negrescens, $C$. paradisi, and $K$. senegalensis. Bar graphs indicate the mean \pm standard error of mean (SEM) of five treatments. ${ }^{*} \mathrm{p}<0.01$ compared with distileed water group. \#p<0.01 compared with $P$. berghei group. 


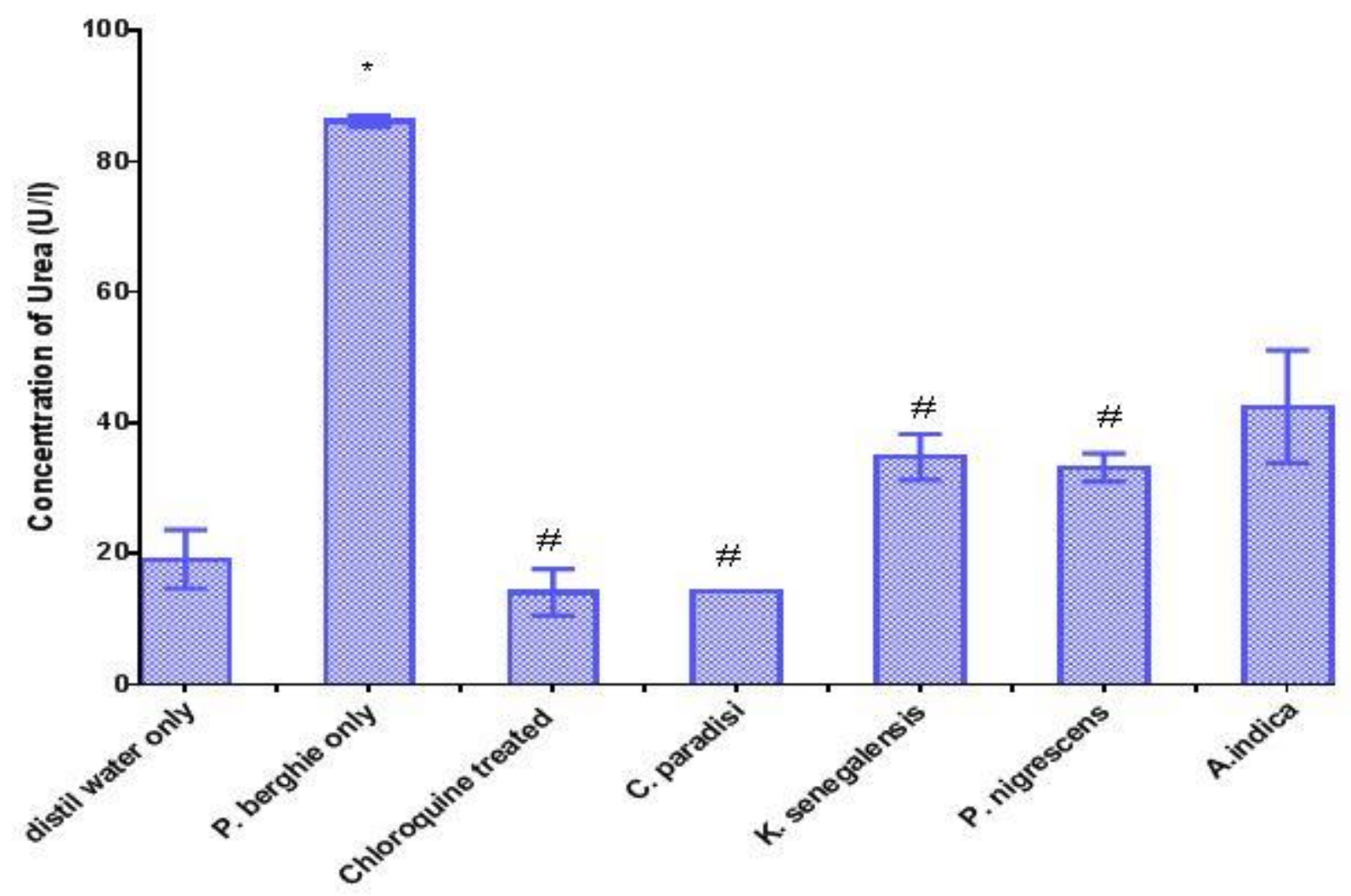

Figure 4: Effect of aqueous extract of A. indica, C. paradisi, P. nigrescens and $K$. senegalensis on Urea in Mice. Group $1=$ negative control. Group $2=$ positive control. Group $3=$ chloroquine treated group. Group $4=100 \mathrm{mg} / \mathrm{kg}$ body weight of aqueous extract of A. indica, P. negrescens, C. paradisi, and $K$. senegalensis. Bar graphs indicate the mean \pm standard error of mean (SEM) of five treatments. ${ }^{*} \mathrm{p}<0.01$ compared with distileed water group. $\# \mathrm{p}<0.01$ compared with $P$. berghei group.

\section{7: Histopathological analysis of the kidney tissue}

Figure $4 \mathrm{ABC}$ enumerated the photomicrographs of representatives of the kidney sections of mice administered with different treatments. The uninfected and chloroquine groups showed normal architecture of the kidney. The glomeruli, renal tubules, interstitial spaces and the medullar ray appeared normal (Fig.4A and C). However, the photomicrographs of the kidney section of group of mice infected and not treated showed abnormal architecture. The renal cortex glomeruli were distorted, the tubules, renal capsule and interstitial spaces appeared abnormal. The interstitial spaces areas indicated strong infiltration (Fig4 B). Figures 4DEFG are the photomicrographs of kidney sections of mice treated with $100 \mathrm{mg} / \mathrm{kg}$ body weight of aqueous extract of $C$. paradise, $K$. senegalensis, $A$. indica and $P$. nigrescens leave extracts respectively. Moderate architecture of the kidney is pronounced in all the treatments. The renal cortex showed normal glomeruli, the renal tubules displayed narrowed lumen and the renal capsule appeared normal. The interstitial spaces areas indicated mild infiltration. 

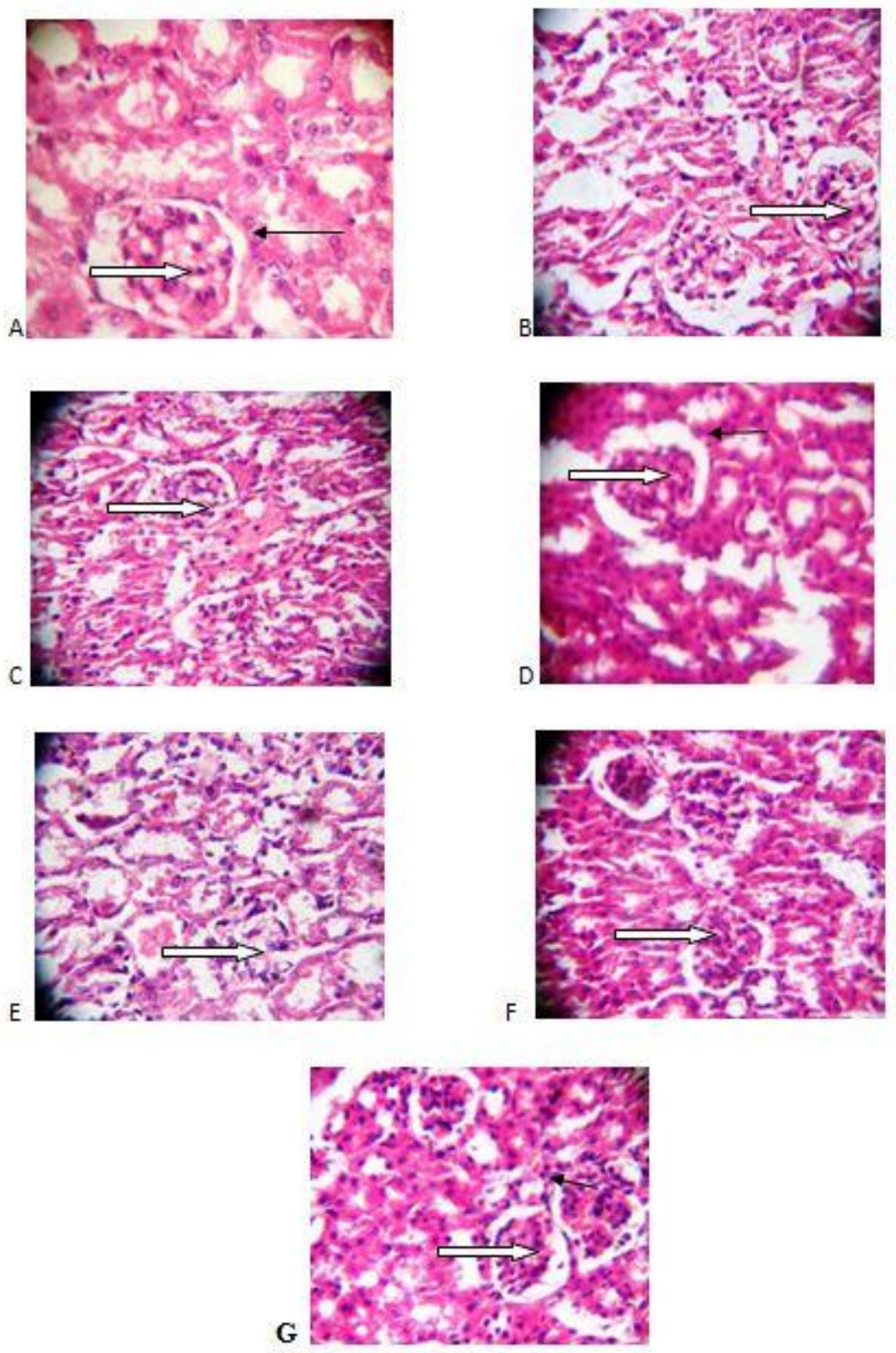

Figure 4 A, B, C and D: Photomicrographs representative of kidney sections stained with H\&E, $\mathrm{X}$ 400. A: are mice not infection and not treated; B: infected with $P$ berghei; $\mathrm{C}$ : chloroquine treated group ; D: treated with $100 \mathrm{mg} / \mathrm{kg}$ body weight of aqueous extract of $C$. paradisi leaves. E: treated with $100 \mathrm{mg} / \mathrm{kg}$ body weight of aqueous extract of $K$. senegalensis. F: treated with $100 \mathrm{mg} / \mathrm{kg}$ body weight of aqueous extract of $A$. indica. G: treated with $100 \mathrm{mg} / \mathrm{kg}$ body weight of aqueous extract of $P$. nigrescens. Glomerulus (White thick arrow) and Tubules (Balck thin arrow).

\subsection{DISCUSSION}

Malaria is a major public health problem, the cause of widespread suffering and premature death in the poorer areas of the Tropical Africa, Asia and Latin America. Human beings can be exposed to malaria through the bite of an infected female anopheles mosquito, blood transfusion, and congenitally from mother to her child $[1,17,18]$. Weakening of renal function during malaria 
infection has been reported, and is a crucial life-threatening impediment of malaria infection $[3,19]$. This study provided information that described the potentials of four antimalarial plants in the reduction of renal injury, plasma urea and creatinine levels during $P$. berghei infection in mice. The rodent parasite, $P$. berghe $i$ was used in studying the activity of potential antimalarial of the plants in mice because it produces diseases similar to those of human plasmodium infection [6]. Since $P$. berghei is chloroquine sensitive, chloroquine was used as the standard antimalarial treatment and ascribed as the positive control in this study. In addition, aqueous extract was used in this study to mimic the preparation by the traditional healer.

Initiation of malaria in mice was observed by increasing level of parasite density in the blood of mice infected with $P$. berghei alone (negative control group), which could cause damage to organs like kidney and liver. The infection of the liver by the sporozoites and the resultant multiplication of the merozoites in the blood cells may account for these injuries $[1,7]$. The results of this study showed that the various leave extracts possessed significant antimalarial activity, which was evident from the chemo suppression and inhibitory activities exhibited in mice. The results of the enzyme assay showed that there was a drastic increase in the concentration of urea of the mice infected with $P$. berghei alone which could be an indication of renal damage. This result was further complemented by the abnormal glomeruli, tubular necrosis and infiltration of vessels by inflammatory cells observed in the kidney tissue of the mice infected with $P$. berghei without treatments.

However, the kidney histopathological analysis of mice treated with aqueous extract of the $K$. senegalensis and chloroquine showed normal glomerulus, as well as very mild tubular necrosis, as the vessel was seen with mild infiltration of inflammatory cells. This result could be attributed to the protective effects of K. senegalensis and chloroquine. Scoparone is a compound identified from the extract of the $K$. senegalensis and known to have exhibited immunosuppressive activities against $P$. berghei [20]. Consequently, scoparone may be responsible for the renal protective activities exhibited by extract of $K$. senegalensis.

Additionally, the urea and creatinine levels in plasma of mice infected with $P$. berghei significantly increased. However, mice treated with $K$. senegalensis, $P$. nigrescens, $C$. paradisi and $A$. indica extracts inhibited this increase to varying degrees. Hence, the extracts had a positive effect on plasma urea and creatinine abnormalities. $P$. nigrescens, $C$. paradisi and $A$. indica extracts showed a significant protective effect to renal tissue during malaria infection in mice infected with $P$. berghei. Increase in the level parasite density of the positive group could cause damage to some organs. The result on the histopathology showed that kidney section of the group of mice treated with $100 \mathrm{mg} / \mathrm{kg}$ body weight of $P$. nigrescens, $C$. paradisi and A. indica extracts had normal glomeruli, insignificant pathological lesion and focal area of mild aggregate of inflammatory cells. Limonin identified in the extract of the $C$. paradisi have been shown to have antimalarial effect. This compound may be responsible for the protective effect exhibited by $C$. paradisi in this study. Malaria parasites inside erythrocytes exert oxidative stress within parasitized red blood cells [21,22,23]. The formation of reactive oxygen species by malaria parasites can be assumed to be countered by antioxidants and phytochemicals in $P$. nigrescens, $C$. paradisi and $A$. indica. Hence, the extracts are thought to prevent the oxidative damage that could have contributed to pathophysiology of many diseases [7]. 
Malaria associated renal injury is suggested to be a consequence of parasite adhesion and exacerbated immune response against oxidative stress products during infection [24]. Therefore, the extent of reactive oxygen species-induced oxidative damage may have been suppressed by antioxidants and active components in the selected extracts.

\section{CONCLUSION}

Among the four plants selected from the selected species used to cure malaria in Nigeria, $C$. paradisi was the most active plant against Plasmodium berghei. It can be concluded that all the selected plant extracts have potent antimalarial and anti-inflammatory components which can subdue kidney tissue injury and reduce urea and creatinine level induced by malaria infection. Hence, the selected plants may be used as supplements in the prevention and treatment of inflammation in malaria. This study has consequently, established the rationale for the traditional use of A. indica, C. paradisi and K. senegalensis for malaria treatments. Further investigation to determine their active components may help in sourcing of new antimalarial drug.

Authors' Contributions: All authors contributed to this study.

\section{Acknowledgments}

We thank Mrs Abubakar Fatimah for her assistance with the initial experiments in this study. We are also grateful to Dr. Akinloye A. for the insightful comments on the write up.

\section{REFERENCES}

1. Greenwood, B.M., Bojang, K.,Whitty, C.J.M., Targett, G.A.T.,2005. Malaria. Lancet 365, 1487-1498.

2. Cowman, A.F., B.S. Crabb. (2006). Invasion of red blood cells by malaria parasites. Cell. 124:755-766.

3. Clark, I.A.,Cowden,W.B, Butcher, G.A.,Hunt, N.H., 1987. Possible roles of tumor necrosis factor in the pathology of malaria. American Journal of Pathology 129, 192-199.

4. Cox-Singh, J and Singh, B.,2008. Knowlesi malaria: newly emergent and of public health importance. Trends in Parasitology 24(9),406-410.

5. Dondorp, A.M (2007). The treatment of severe Malaria. Trans R Soc Trop Med Hyg, 101: 633-634.

6. Okokon, J.E., Ofodun, K.C., Ajibesin, K.K., Danladi, B, Gamaliel KS. (2005). Pharmacological screening and evaluation of anti-plasmodial activity of Croton zambesicus against Plasmodium berghei infection in mice. Indian J Pharmacol; 37(4): 243-246.

7. Oshimi, S., Deguchi, J., Hirasawa,Y., Ekasari, W., Widyawaruyanti, A.,Wahyuni, T.S., Zaini, N.C., Shirota, O., Morita, H., Cassiarins, C.E., 2009. Antiplasmodial alkaloids from the flowers of Cassia siamea. Journal of Natural Products 72, 1899-1901.

8. Noedl, H., Se, Y., Socheat, D., Fukuda, M., 2008. Evidence of Aremisinin-Resistant Malaria in western Cambodia. New England Journal of Medicine :359, 2619-2620.

9. Pyae-Phyo, A., Nkhoma, S., Stepniewska, K., Ashley, E.A., Nair, S., McGready, R., Moo, C., ler. Al-Saai, S., Dondorp, A.M., Lwin, K.M., Singhasivanon, P., Day, N.P.J., White, N.J., 
Anderson, T.J.C., Nosten, F., 2012. Emergence of artemisinin- resistant malaria on the western border of Thailand: a longitudinal study. Lancet 379,1960-1966.

10. Dalziel JM (1956). Useful Plants of West Tropical Africa. Crown Agents for the Colonies, London, pp. 179-183.

11. 11. Olayinka A.T, Oduyebo O, Ogunsola FT, Odugbemi T. (1997). Prevalence of multiresistant strains of Pseudomonas aeruginosa isolated at the Lagos University Teaching Hospital from 1994-1996. Niger. Qt. J. Hosp. Med. 7:373-376.

12. Kuashik, N., K. Kumar, S. Kumar and S. Roy (2007). Genetic variability and divergence studies in seed traits and oil content of Jatropha (Jatropha curcas L.) accessions. Biomass and Bioenergy 31:497-502.

13. Adetola, Adedapo, A. A., Abatan, M. O. and Olorunsogo, O.O., (2004). Toxic effects of some plants in the genus Euphorbia on haematological and biochemical parameters of rats Veterinarski Arhiv 74 (1), 53-62.

14. Peters W, Portus JH, Robinson BL. (1975). The chemotherapy of rodent malaria XXII. The value of drug resistant strains of P. berghei in screening for blood schizonticidal activity. Ann Trop Med Parasitol. 69:155-71.

15. Peters W, Fleck SL, Robinson BL, Stewart LB, Jefford CW. (2002). The chemotherapy of rodent malaria. LX. The importance of formulation in evaluating the blood schizontocidal activity of some endoperoxide antimalarials. Ann Trop Med Parasitol. 96:559-73.

16. Dacie, J.V. and Lewis, S.M. (2000). Practical Haematology. 9th Edition Churchill Livingstone. Volume 4, 1983, PP 23-56.

17. Bruce, C.L. (1981). Alphonse Laveran's discovery 100 years ago and today's global fight against Malaria. J.R. Soc Med, 74: 531-600.

18. Clark, I.A. and Cowden, W. B. (2003). The Pathophysiology of Falciparum malaria. Pharmacology and Therapeutics, 99: 221-260.

19. Chitnis, C.E., and Blackman, M.J. (2000). Host cell invasion by malaria. Parasitol. Today. 16:411-415.

20. Guissou, A.J. Moes Lompo, M., J.B. Nikiema, I.P. and J. Fontaine, (1998). The topical antiinflammatory effect of chloroform extract from Khaya senegalensis stem barks. Phytother. Res., 12: 448-450.

21. Rayner, J.C., M.R. Galinski, P. Ingravallo, J.W. Barnwell. (2000). Two Plasmodium falciparum genes express merozoite proteins that are related to Plasmodium vivax and

22. Plasmodium yoelii adhesive proteins involved in host cell selection and invasion. Proc. Natl. Acad. Sci. USA. 97:9648-9653.

23. Duraisingh, M.T., Triglia, T., Ralph, S.A., Rayner, J.C., Barnwell, J.W., Mafadden, G.I., and Cowman, A.F. (2001). Phenotype variation of Plasmodium falciparum merozoite proteins direct receptor targeting for invasion of human erythrocytes. EMBO J.22:1047-1057.

24. Motta, M.M., G. Pradel, J.P. Vanderberg, J.C. Hafalla, U. Frevert, R.S. Nussenzweig, V.Nussenzweig, A. Rodríguez. (2001). Migration of Plasmodium sporozoites through cells before infection. Science. 291:141-144.

25. Baer, K., M. Roosevelt, A.B. Clarkson, N. van Rooijen, T. Schnieder, U. Frevert. (2007). Kupffer cells are obligatory for Plasmodium yoelii sporozoite infection of the liver. Cell. Microbiol. 9:397-412. 